\title{
The chairperson and CEO roles interaction and responses to strategic tensions
}

Article

Accepted Version

Morais, F., Kakabadse, N. and Kakabadse, A. (2018) The chairperson and CEO roles interaction and responses to strategic tensions. Corporate Governance: The International Journal of Business in Society, 18 (1). pp. 143-164. ISSN 1472-0701 doi: https://doi.org/10.1108/cg-05-2017-0092 Available at https://centaur.reading.ac.uk/71965/

It is advisable to refer to the publisher's version if you intend to cite from the work. See Guidance on citing.

To link to this article DOI: http://dx.doi.org/10.1108/cg-05-2017-0092

Publisher: Emerald

All outputs in CentAUR are protected by Intellectual Property Rights law, including copyright law. Copyright and IPR is retained by the creators or other copyright holders. Terms and conditions for use of this material are defined in the End User Agreement.

www.reading.ac.uk/centaur 
Central Archive at the University of Reading

Reading's research outputs online 


\title{
The chairperson and CEO roles interaction and responses to strategic tensions
}

\begin{abstract}
Purpose: This paper utilises Stewart's model of role as a lenses from which to explore chairperson and CEO role dynamics in addressing strategic paradox and tension.

Design/methodology/approach: The paper draws on 29 semi-structured, in-depth interviews with chairpersons and CEOs of UK-listed companies. Interview data is subjected to role analysis using Stewart's (1982) Demands-Constraints-Choice (DCC) model of role.

Findings (mandatory): Findings indicate that relationship levels of trust, communication and chairperson time, enable strategic tensions to be raised and confronted in the relationship reducing defensiveness. Two distinct approaches to handle strategic tensions are found. The CEO-led approach predominates and rests on less flexible role boundaries, requiring the chairperson to proactively identify strategic tensions and perform an advisory/mentoring role. The shared leadership approach, less prevalent, rests on highly flexible role boundaries where the skills and experience of each incumbent become more relevant, enabling the separation of efforts and integration of strategic tensions in the relationship in a 'dynamic complementarity of function'.
\end{abstract}

Research limitations: The study only applies to the UK context and is limited to contexts where CEO and chairperson roles are separate. The study draws on individual perceptions of chairperson and CEOs (i.e. not pairs).

Practical Implications: The study provides insights to practicing CEOs and chairperson on two distinct ways of working through strategic paradox and tensions.

Originality/value: The study adds to the scarce literature at chairperson and CEO roles and strategic paradox and tension.

Keywords: CEO; Chairpersons; Role Theory; Strategic Paradox; Tensions. 


\section{Introduction}

Extant literature links frame-breaking, discontinuous change with the emergence of strategic paradoxes which corporate leadership needs to face. This is why firm-level discontinuous change theorists have since been interested in strategic paradoxes arising in contexts of far-reaching organisational change (e.g. Smith et al., 2010; Smith and Tushman, 2005), and why organisational/strategic paradox scholars have equally selected such contexts to examine the emergence of, and response to organisational/strategic paradox (e.g. Jarzabkowski et al., 2013; Schmitt and Raisch, 2013; Tse, 2013).

In the UK, the digital revolution brought discontinuous change to many traditional print and entertainment firms, such as EMI, HMV and Yell Group. Corporate leadership in these firms had to keep exploiting their declining legacy business, whilst simultaneously exploring completely new ways of doing business in the digital age, remaining competitive, and attempting to survive. These types of situations often require business leaders to be able to handle strategic tensions that arise from the clash between the legacy and the emerging business in terms of contrasting and contradictory ways of organizing, performing and learning (e.g. Smith and Lewis, 2011; Schmitt and Raisch, 2013 ). This leaves leaders having to make sense of, and navigate through short-term/long-term, exploration/exploitation, retrenchment/recovery and perhaps other types of strategic paradoxes (e.g. Lewis et al., 2014; Smith and Lewis, 2011; Schmitt and Raisch, 2013). Most studies on strategic paradoxes, invariably assign to the CEO the central role in effectively leading the firm through strategic tension (Gilbert, 2006; Lewis et al., 2014; Tushman et al., 2011) neglecting the relationship between the roles of Chairperson and CEO (e.g. Kakabadse et al., 2010; Roberts and Stiles, 1999; Stewart, 1991) as a critical factor that constrains and enables responses to strategic paradoxical tension. According to agency theory the board's role is to debate, approve, monitor and control strategy and its implementation by the CEO (e.g. Fama and Jensen, 1983; Jensen and Meckling, 1976) 
prescribing that the separation of the roles of chairperson and CEO, provides an ideal leadership structure to arrive at independent and effective monitoring and control. Sundaramurthy and Lewis (2003) posit that role combination during poor performance may result in escalating commitment (e.g. Brockner, 1992) and strategic persistence (e.g. Audia et al., 2000), heralding firms into vicious reinforcing cycles.

In this paper, we explore how the role dynamics of the chairperson-CEO relationship constrain or enable/support responses to strategic paradoxes. These are defined as performing tensions at the organisational level that "stem from the plurality of stakeholders and result in competing strategies and goals" (Smith and Lewis, 2011, p. 384). A caveat must be made at this point. We were unable to select pairs of CEOs and chairpersons; hence this paper reports individual perceptions of the roles of chairpersons and CEOs and their interplay in responding to strategic paradoxes. Despite this obvious limitation, research on the chairperson-CEO relationship is sparse, as access to respondents is often difficult (e.g. Leblanc and Schwartz, 2007). As far as we can assess, Stewart's 1991 study is the only relevant qualitative study that was able to collect pairs of respondents. Conscious of this limitation, we decided nevertheless to use our data to reach a greater understanding of how the critical and pivotal interplay between CEO and chairperson roles, enables and constrains responses to strategic paradoxes.

This paper finds two distinct approaches used by chairpersons and CEOs to handle strategic tensions: shared-leadership and CEO-led. Whereas in Stewart (1991) a partner style of relationship was prevalent, the findings in this study indicate the prevalence of a CEO-led approach which requires: i) an active chairperson able negotiate flexible role boundaries; ii) proactively identification of strategic tensions the CEO is grappling with or unaware of, and; iii) performing a mentoring role so as to positively influence CEO cognitive recognition of tensions and behavior. A second approach to handling tensions, agrees with Stewart's earlier paper by pointing to a shared leadership approach, which includes both chairperson roles as 
'partner' and 'executive' (Stewart, 1991). However, an important difference, is that the 'complementarity of function' (Hodgson et al., 1964) that characterizes the partnership does not follow a static division of responsibilities. Rather, it requires role boundaries that are highly flexible, and a complementarity of function that is not static but continuously negotiated according to circumstances.

The paper is organised as follows: literature on strategic paradox and tensions is briefly reviewed. This is followed by a discussion on agency and stewardship theories of the board and corresponding board leadership structures, as well as the chairperson-CEO relationship. We then present a detailed qualitative, interview-based methodology guided by role theory (Stewart, 1982). Since early research work developed by Professor Rosemary Stewart and colleagues in understanding managerial jobs (e.g. Fondas and Stewart, 1994; Stewart, 1982) and the interplay between District General Managers and chairpersons in the NHS (Stewart, 1991), role theory has not been sufficiently acknowledged as a powerful lens from which to understand and explain managerial and other board roles' behaviour. Some exceptions exist (e.g. Kakabadse et al., 2006), but the norm has been to overlook this important theory. The paper proceeds with presenting and critically discussing research findings and ends with a concluding section outlining contributions, future research opportunities, and research limitations.

\section{Literature Review}

\section{Strategic Paradox}

Smith and Lewis (2011) have resolved decades of terminology imprecision in paradox literature by developing a consensual definition of paradox. We concur with their definition of paradox as "contradictory yet interrelated elements that exist simultaneously and persist over time" (Smith and Lewis, 2011: 382). Paradoxes of performing refer to the idea that "plurality 
fosters multiple and competing goals as stakeholders seek divergent success' (Smith and Lewis, 2011, p.383). Performing paradoxes that occur at the firm level are also called strategic paradoxes (Smith, 2014; Smith and Lewis, 2011). Strategic paradoxes are firm-level performing tensions arising from competing strategies and goals (Smith and Lewis, 2011) and include, for example, tensions between exploration and exploitation strategies (Smith, 2014; Smith et al., 2010). Strategic paradoxes are seen as "particularly prevalent, challenging, and consequential to an organization's fate" (Smith, 2014, p.1593).

How the CEO role sustains and responds to strategic paradoxes and tensions has been relatively explored (Smith, 2014) as being at the genesis, for example, of strategic innovation (Smith et al., 2010; Smith and Tushman, 2005; Tse, 2013), strategic agility (Lewis et al., 2014) and corporate sustainability (Hahn et al., 2014; Hahn et al., 2015). However, how strategic paradoxes are handled within the critical chairperson-CEO relationship is still little understood. Studies have shown that chairpersons and boards face a performing paradox in which they must simultaneously control and collaborate with the CEO (Sundaramurthy and Lewis, 2003). Moreover, Farjoun (2010) elaborated compelling arguments for stability and change as an unavoidable duality, whereby organizations need to be able to reconcile stability, reliability and exploitation with change, innovation, and exploration. Given the legal and practical prescriptions of the chairperson and CEO roles, (i.e. the chairperson role often entails a greater orientation toward stability, consensus, and protection of value, whereas the CEO role focuses on entrepreneurial activity, change, and maximization of value), it may be that these roles have different preferences in terms of stability and change, and exploration and exploitation, for example. This then has the potential to impact on how the relationship is defined and how strategic tensions are handled. 


\section{The chairperson-CEO relationship}

From its inception (Cadbury Committee Report, 1992) the requirement for independence between the board and the management has been a key aspect of the UK governance regime which has driven the board's role, composition and structure, including also the constellation of individual director roles and expectations of behaviour. The quest for independence of the board from the executive as a critical component of effective monitoring and control (Jensen and Meckling, 1976; Jensen, 1993; Morck et al., 1988) led to successive regulatory changes, which resulted, among other things, in: a greater, even dominating, proportion of external, independent non-executive directors in relation to executives; the separation of CEO and chairperson positions; and an increased use of committees staffed by external, independent nonexecutive directors. These, along with further refinements and guidance to the code (e.g. FRC, 2011, 2016), affirm the roles of chairperson and CEO as pivotal to the board's effectiveness. The clarification provided by the FRC on board effectiveness also recognises the often tensiongenerating relationship between the chairperson and the CEO which is pivotal to the effectiveness of the board as a whole. It further lays down a requirement that the "chairman and the CEO roles should be set out in writing and agreed by the board" and "particular attention [should be] paid to areas of potential overlap" (FRC, 2011:7).

The regulatory move from a structuralist approach to board governance focusing on independence and compliance, to one that emphasises role behaviour - has been paralleled and often informed by research that revealed the insufficiency of structural and compositional considerations. As long ago as the 1970s, Argenti (1976) identified instances of “one-man rule", combined chairperson and chief executive roles, a non-participative board, an unbalanced top management team, a lack of management depth and weak financial function as the six principal symptoms of corporate collapse. Subsequent studies have supported some of these aspects. Role duality leads to unfettered CEO power, which combined with lack of monitoring often leads to 
corporate failure (Daily and Dalton, 1993) or weakened company performance (e.g. Coles et al., 2001). Others found a positive correlation between role separation and corporate performance (Donaldson and Davies, 1991; Slatter and Lovett, 1999). But other researchers reached contradictory results even when introducing contingency factors. Boyd (1995) found role duality leads to better return on investment (ROI) in companies that are resourceconstrained or have higher complexity. Haleblian and Finkelstein (1993) found that role duality was associated with worse performance in firms experiencing turbulent environments. These frustrating and inconclusive results led researchers starting to focus on the interaction and relationship between the chairperson and the CEO.

The centrality of the chairperson-CEO relationship is commonly referred to in governance regimes where these roles are held separate, such as the UK. This relationship is often described as pivotal and sacred (Kakabadse et al., 2006; Leblanc and Gillies, 2005; Levrau and Van Den Berghe, 2013) or the 'fulcrum around which directing is levered', and is considered highly contextual in nature (Pye, 2005). The study of how role arrangements are formed and impact each other was first developed by Hodgson et al. (1965) which referred to a process of "emotional division of labor" and specialization of function by each role-holder, so that they become complementary and form a balanced "integrated whole" (Hodgson et al., 1965, p. xxi). Referring to pairs as a stable and effective 'role constellation', Hodgson explained how some pairs were found to specialize in internal demands and external, boundary-spanning activities (Hodgson et al. 1965). Chitayat's study (1984) which investigated the working relationships between Israeli CEOs and chairpersons, found that whilst there was a great variation in the relative functions depending on firm's structure and the incumbent's personality, the role of the chairperson as consulting and coaching the CEO emerged as the most important. 
Stewart's longitudinal study (1991) of 20 relationships between chairpersons and their general managers found that the chairperson and CEO roles (when separated) are impacted by organisational structure, personality, and the time that the chairperson devotes to the role. The study identifies and describes five chairperson roles in relation to the CEO: partner; executive; mentor; consultant; distant (Stewart, 1991). Stewart concluded that the roles of chairperson and general managers are highly interdependent, and that this mutual dependence is highly contextual in nature (Stewart, 1991). More recent studies indicate that a complementary relationship between the chairperson and CEO provides ' $a$ context in which the CEO can think provisionally in a way that acknowledges the ambiguity and uncertainty that is the ground of decision-making' (Roberts, 2002, p.504). 'Building the basis for trust' between the two roles by enabling open communication of concerns avoids misunderstandings about the true intentions of each other and requires a "high level of routine contact between the two" (Roberts, 2002, p.502). A further study by Kakabadse et al. (2006) referred to role delineation as the critical element and a distinct advantage of the UK leadership structure in relation to that of the US. In this way "tensions between the two could be attributed both to the idiosyncrasies of their personal interaction and also to poorly delineated, peripheral responsibilities" (Kakabadse et al., 2006, p. 142). The relationship between chairperson and CEOs was seen as encompassing two key qualities: having 'personal chemistry' and an 'ability to interpret information and events in a mutually synergistic manner.' (Kakabadse et al., 2006, p.144). Similarly, in a subsequent study based on 900 interviews with board members, these critical qualities have been reconceptualised as 'shared sensemaking' and 'affective philos' as two essential preconditions for chairperson-CEO relationship effectiveness (Kakabadse and Kakabadse, 2008).

Studies on the dyadic relationship between the roles of chairperson and CEO focused much more on how the roles are negotiated to withstand role-based tensions, but much less on 
how the relationship responds to latent tensions in the environment that are made salient by resource scarcity conditions (Smith and Lewis, 2011).

The next sections provide details on the study design, including the research approach, sample selection, and methods for data collection and analysis.

\section{Methods}

\section{Sample Selection and Composition}

The study uses non-probability, purposive sampling where the selection criteria are derived primarily from the research questions (Patton, 2002). Creswell (2007) indicates that 25 to 30 interviews should be undertaken for any general qualitative studies where the sample is heterogeneous. Table I provides an overview of the sample composition.

Table I: Sample Composition by Role

\begin{tabular}{|c|c|c|c|c|c|c|}
\hline \multirow{2}{*}{ Role Type } & \multirow{2}{*}{$\begin{array}{c}\text { Current } \\
\text { Main } \\
\text { Role }\end{array}$} & \multirow{2}{*}{$\begin{array}{c}\text { Average } \\
\text { Age } \\
\text { (Years) }\end{array}$} & \multirow{2}{*}{$\begin{array}{c}\text { Held } \\
\text { Roles* }\end{array}$} & \multicolumn{2}{|c|}{ Gender } & \multirow[b]{2}{*}{ Ethnicity } \\
\hline & & & & $\mathbf{M}$ & $\mathbf{F}$ & \\
\hline Chief Executive Officer (CEO) & 17 & 54.7 & 24 & 15 & 2 & White British \\
\hline Chairperson & 12 & 61.6 & 21 & 12 & 0 & White British \\
\hline Totals & 29 & 58 & 45 & 27 & 2 & White British \\
\hline
\end{tabular}

*Note: held roles refer to the roles participants held at the time of reported discontinuous change.

We conducted semi-structured interviews during the year of 2014 with 29 chairpersons and CEOs based in the city of London. Although we reached theoretical saturation after 20 interviews, we sought to achieve higher confidence in our findings, particularly by seeking access to female directors. Most of the participants were male (93.1\%), with an average age of 58. Participants included 17 who held the CEO position as their current main role, and 12 who had a chairpersonship as their current main role. All participants held multi-directorships; however, as participants were asked to discuss different experiences they have faced in their career as board members, the total number of CEO and chairperson roles examined was in fact 24 and 21 respectively. All participants were from a white British background. 


\section{Research approach and theoretical framework}

We devised and conducted an exploratory, qualitative research design (Guba and Lincoln, 2005; Saunders et al., 2009; Silverman, 2013). The study uses the role model of DemandsConstraints-Choices (DCC) (Stewart, 1982) as a lens from which to analyse the roles of CEO and chairperson.

A number of role-based models have been developed. Some, such as the fixed-job model (e.g. Dawis and Lofquist, 1969), view both the role and the incumbent as static and complete, while the interpersonal role model (e.g. Kahn et al., 1964) sees role behaviour as dynamic, contingent of organisational, interpersonal and personality (of leader or member) factors. However, both of these models define the role incumbent as passive. More enlightened models, such as the interdependent role systems models (e.g. Katz and Kahn, 1966), allow the role incumbent to be active in adjusting his/her personal belief systems in relation to those of the organisation. The "theory of instrumentality" (e.g. Graen, 1969) allows the role incumbent (rational) choice about which role model (e.g. leader or interested peers) to follow, according to the perceived relative utility which the incumbent can rationally expect. Along the same line, the "effective performance model" posits that role behaviour is a function of the degree to which the role incumbent believes that a link exists between high role performance and desired payouts, and, conversely, that there is no link between poor performance and high payouts (Graen, 1976). These two models emphasise the contribution of reward systems in enforcing organisationally desired role behaviour.

Subsequent models of roles have recognised role incumbents' proactivity in both modifying expectations (e.g. Fondas and Stewart, 1990, 1994) and in choosing how to enact their role (i.e. behavioural choices), given the contextual and individual constraints and opportunities presented (Stewart, 1967, 1976, 1982). 
Prominent among these is the work of Professor Rosemary Stewart (e.g. Lowe, 2003). Stewart's celebrated Demands-Constraints--Choices (DCC) model has become established as one of the main explanatory theory of role, accounting for variabilities in both jobs and role incumbent behaviour (Stewart, 1982). In short, the DCC model posits that managers' available choices or opportunities within the role are dynamically influenced by role demands (i.e. what is expected of any incumbent in terms of task and output in order to stay in the job) and internal and external constraints, which can be personal (e.g. own preferences) or organisational (e.g. reward systems, training), or they can be of physical (e.g. resources) or social and cultural natures (e.g. legal norms, peer attitudes, leadership) (Stewart, 1982, 2003). The nature of demands and constraints is situational, so the available behavioural choices change accordingly (Stewart, 2003). Choices are enacted in three domains: i) the aspects of the role to which the incumbent chooses to devote more time and commitment of resources; ii) the tasks that are delegated; iii) boundary management (Stewart, 1982). The DCC model is consistent with observations by Hales (1986), as it allows for variation and contingency, choice and negotiation, pressure and conflict, and reaction and non-reflection, stressing that managerial (and, for that matter, directors') activities “may be competing, even contradictory” (Hales, 1986:102).

In addition to its simplicity and dynamic nature, the model offers the opportunity to locate and explore strategic tensions inside the boardroom and at different levels of analysis, by examining the nature of demands, constraints and choices.

Furthermore, role theory, and particularly the work of Rosemary Stewart, has been widely recognised for its contribution to qualitative methodologies (Parry, 2003), often seen as "exemplars of the argument for qualitative reasoning rather than quantitative analysis for studying a complex and weakly understood phenomena” (Kroeck, 2003:204).

A number of previous studies have successfully used role theory to examine boardroom dynamics: for example, the chairperson-CEO relationship (Stewart, 1991; Roberts and Stiles, 
1999; Kakabadse, Kakabadse and Barratt, 2006) as well as the chairperson role and skill-set (Kakabadse and Kakabadse, 2007b).

Stewart's examination of the chairperson-CEO relationship in the UK National Health Service (NHS) using her own DCC model was able not only to examine the dependent nature of this relationship but, importantly, how the degree of this dependence was contextually determined (Stewart, 1991). For Roberts and Stiles (1999), role theory is useful in examining the interpersonal nature of roles, and the expectations formed and negotiated within a particular boardroom formative context, stressing the importance of bringing together process and contextual research perspectives. Other authors (Kakabadse et al., 2006) have used role theory as a lens through which to examine the chair-CEO relationship in context and to emphasise the relational dimensions of effective performance, and also to "gain consistency across interviews" while examining the role and contribution of 103 UK, US and Australian chairpersons (Kakabadse and Kakabadse, 2007b).

In conclusion, role theory - particularly the DCC model of role - fits both the exploratory nature of research as well as the questions it seeks to answer. Role analysis (e.g. Stewart, 1982) was therefore used as part of the study methodology.

\section{Data Collection and analysis procedures}

We asked each participant before the interview, via a letter of introduction, to reflect on examples where they have experienced strong strategic tensions whilst enacting their roles as CEO or chairperson. Semi-structured interviews, as recommended for qualitative exploratory studies (Gillham, 2005; Robson, 2002), lasted between 60 and 120 minutes, and were taperecorded and subsequently transcribed, following participants' consent. We derived preinterview themes from the initial literature review, research questions, and a background 
analysis of the participants' biographies. Typical questions that formed the basis of the inquiry were:

- What were the key strategic tensions/competing strategic demands that you were facing in that situation?

- How was the relationship with your CEO/chairperson? Did it change during that time?

- Who was leading the response to those particular strategic tensions?

- What was the role of the chairperson in supporting you/constraining you in handling those tensions?

Interview transcripts were divided according to role experiences (CEO and chairperson) and each of them were separately coded (theory driven coding) for role demands, constraints, and choices (Stewart, 1982; 1991) ensuring a common frame and consistency in the analysis across interviews (Kakabadse and Kakabadse, 2007a). In addition, certain aspects of role were openly coded (Bryman, 1988; Glaser and Strauss, 1967; Silverman, 2013) as supports, that is, elements of the role-context that enabled the role occupant to work through demands, overcome constraints and/or make particular choices. Thematic analysis (Boyatzis, 1998; Braun and Clarke, 2006; Saunders et al., 2009; Silverman, 2013) proceeded by identifying overarching themes that "cut across" demands, constraints, choices and supports for both the role of the chairperson and the role of the CEO. The following table II provides an overview of the coding process. 
Table II: Thematic Analysis using the DCC Model

\begin{tabular}{|c|c|c|c|}
\hline \multicolumn{3}{|c|}{ Role Analysis (Theory and open coding) } & \multirow{2}{*}{$\begin{array}{l}\text { Themes and Sub-themes } \\
\text { (Similarities and differences across } \\
\text { Chairpersons and CEOs in terms of } \\
\text { strategic competing demands, } \\
\text { constraints, choices and supports) }\end{array}$} \\
\hline DCC Model & $\begin{array}{l}\text { Chairperson } \\
\text { (Examples) }\end{array}$ & $\begin{array}{l}\text { CEO } \\
\text { (Examples) }\end{array}$ & \\
\hline Demands & $\begin{array}{l}\text { - Ensure sound strategy development } \\
\text { and execution } \\
\text { - Ensure balanced short and long-term } \\
\text { goals } \\
\text { - Judge the pace and scale of change } \\
\text { - Ensure a balance between } \\
\text { exploration and exploitation } \\
\text { - Develop a working relationship with } \\
\text { CEO } \\
\text { - Manage board meetings effectively }\end{array}$ & $\begin{array}{l}\text { - Develop and implement corporate } \\
\text { strategy } \\
\text { - Ensure balanced short and long- } \\
\text { term goals } \\
\text { - Judge the pace and scale of change } \\
\text { - Ensure a balance between } \\
\text { exploration and exploitation } \\
\text { - Develop a working relationship } \\
\text { with CEO } \\
\text { - Lead the top executive team }\end{array}$ & \multirow{4}{*}{$\begin{array}{l}\text { Theme 1: The Nature and } \\
\text { Perception of strategic tensions by } \\
\text { chairpersons and CEOs } \\
\text { (Which competing strategic } \\
\text { demands and tensions are faced?) } \\
\quad \downarrow \\
\text { Theme 2: Chairperson-CEO } \\
\text { Relationship Qualities for Handling } \\
\text { Strategic Tensions } \\
\text { - Chairperson time and } \\
\text { relationship trust } \\
\text { - Complementary skills, } \\
\quad \text { experiences and } \\
\text { perspectives } \\
\text { (Which qualities are displayed in } \\
\text { the relationship when handling } \\
\text { those tensions?) } \\
\quad \downarrow \\
\text { Theme 3: Delineating Role } \\
\text { Boundaries } \\
\text { (How are roles delineated between } \\
\text { chairpersons and CEOs to respond } \\
\text { to the competing strategic } \\
\text { demands/tensions) } \\
\downarrow \\
\text { Theme 4: Responses to tensions: } \\
\text { shared leadership and CEO-Led } \\
\text { (What roles does the chairperson } \\
\text { play in supporting the CEO to } \\
\text { handle strategic tensions?) }\end{array}$} \\
\hline Constraints & $\begin{array}{l}\text { - CEO behavior } \\
\text { - Lack of trust with/from CEO } \\
\text { - Lack of time } \\
\text { - Lack of independence } \\
\text { - Lack of industry experience } \\
\text { - Poor boundary delineation with CEO } \\
\text { (...) }\end{array}$ & $\begin{array}{l}\text { - Poor chairperson } \\
\text { - Lack of trust with/from chairperson } \\
\text { - Chairperson lack of time } \\
\text { - Chairperson not independent } \\
\text { - Chairperson with little industry } \\
\text { knowledge } \\
\text { - Poor boundary delineation with } \\
\text { chairperson }(\ldots)\end{array}$ & \\
\hline Choices & $\begin{array}{l}\text { - When to challenge, advise, mentor } \\
\text { or partner with the CEO } \\
\text { - When to set stricter boundaries } \\
\text { - When to based relationship on skills } \\
\text { and capabilities } \\
\text { - Frequency of communication }(. . .)\end{array}$ & $\begin{array}{l}\text { - When to accept challenge or seek } \\
\text { advise } \\
\text { - How to react to stricter boundaries } \\
\text { - When to base the relationship on } \\
\text { skills and capabilities } \\
\text { - Frequency of communication (...) }\end{array}$ & \\
\hline $\begin{array}{l}\text { Supports } \\
\text { (added) }\end{array}$ & $\begin{array}{l}\text { - The Senior Independent Director } \\
\text { Support } \\
\text { - Special advisors support } \\
\text { - The CEO support in removing a } \\
\text { non-performing board member } \\
\text { (...) }\end{array}$ & $\begin{array}{l}\text { - The chairperson emotional support } \\
\text { - The chairperson advise } \\
\text { - The board support } \\
\text { - Special advisors support } \\
\text { (..) }\end{array}$ & \\
\hline
\end{tabular}

It was possible to identify the nature of the strategic competing demands and tensions commonly perceived and faced by chairpersons and CEOs. A second theme which emerged, related to the qualities of the chairperson-CEO relationship which support, constrain or shape role boundary delineation and responses to strategic competing demands and tensions. The third theme, looked at perceptions and choices of role boundary delineation between chairpersons and CEOs and implications for the roles the chairperson can play in relation to the CEO (forth theme). The pattern of relationships between the four themes enabled the emergence of two distinct models of how chairpersons and CEOs work together to handle strategic tensions. 


\section{Findings and Discussion}

Research findings indicate that chairpersons and CEOs of large UK companies perceive the chairperson-CEO relationship as being of critical importance for effectively navigating through strategic paradoxical tensions. Four themes emerged from the thematic analysis undertaken: i) Nature and perceptions of strategic tensions faced by chairperson and CEOs; ii) Chairperson-CEO relationship qualities for handling strategic tensions; iii) Delineating role boundaries and; iv) Responses to strategic tensions: leadership approaches.

These themes are discussed in the next sections, supported by evidentiary quotes as necessary.

The nature and perceptions of strategic tensions faced by Chairpersons and CEOs

Findings arising from this study show that a number of (perceived) strategic tensions (i.e. exploration and exploitation; short and long-term) are handled in the Chairperson-CEO relationship. Technology disruption and other external disruptive factors such as regulation emerged as critical contexts within which tensions emerge, introducing high levels of uncertainty about the firms's future competitive advantage.

The CEO of a large retailer faced the tension of how to sustain today's competitive advantage based on retail shops in a highly competitive market, whilst simultaneously investing in online presence, which could compete with the existing business, and would require contrasting and contradictory ways of performing his role.

"You've got too much space and too many players, so you've got the perfect storm. And online is the big thing. If you get it right you could be successful and I do, I believe that $40 \%$ of all sales could be online and groceries over the next 20, 30 years, yes I do. The CEO needs to be able to pat his head and rub his tummy." (CEO)

Chairpersons also referred to similar events as triggering strategic tensions to be faced. The chairperson of a pharmaceutical company explained how Obama Care fundamentally threatened to disrupt the existing business model and competitive dynamics. 
Healthcare budgets around the world are under pressure, we didn't feel that the US pricing model was going to be long term sustainable. The ObamaCare was just emerging as a way forward but fundamentally ObamaCare was about a trade-off for lower prices against better coverage and more people being captured, and we weren't necessarily convinced that there would be more people captured, but nevertheless lower pricing was going to change the environment." (Chairperson)

Many chairpersons ascribed the emergence of strategic tensions to digital disruption to the legacy business model, often coupled with a recessionary environment.

"Face a declining EBITDA from a traditionally declining print business, a business that turned down heavily in a recession and the debt constant so it equals a big problem." (Chairperson)

"It was very challenging going from print publishing houses to a digital content services company, so it's a challenge". (Chairperson)

Findings indicate that the type of strategic tensions are irrelevant in relation to how the chairperson-CEO relationship works in addressing them, that is, the same type of strategic tension might be handled differently by different chairperson-CEOs, and different tensions might be handled in similar ways. For example, two large media companies undergoing restructuring both described raising tensions of exploration-exploitation and tight-loose coupling in the relationship, yet differed in their approach to handling them effectively. In the first company, a shared leadership approach between the chairperson and CEO was utilized (akin to Stewart's chairperson role as Partner), whereas in the other, a CEO-led type of approach (akin to Stewart's chairperson role as Mentor) was successfully utilised. In some cases, interviewees revealed that the relationship was not able to effectively address the strategic tensions being faced. In one large infrastructure company, there was a failure to effectively address tensions arising from short-term/operational and long-term/strategic elements of the business. The CEO noted that he needed a shared leadership model to be able to provide separate leadership to each side of the strategic tension, but the role of the chairperson was that of the distant chairperson (Stewart, 1991). In contrast, a consultancy company facing a similar strategic tension effectively handled it using a CEO-led approach, where the chairperson acted 
as a coach and counsel to the CEO to enable him to reconcile competing demands from short and long-term shareholders. These examples show that the type of strategic tensions are unimportant, as long as the relationship is able to recognise, raise, and accept the tensions, and then negotiate the role boundaries in such as to enable tensions to be effectively addressed. To be able to recognise, raise and accept tensions in the chairperson-CEO relationship, there are critical relationship qualities and attributes that need to be present.

\section{Chairperson-CEO Relationship Qualities for Handling Strategic Tensions}

Chairperson time and relationship trust. The chairperson-CEO relationship needs to have a number of attributes for any leadership approach to be effective. Directors participating in the study emphasised the imperative for this relationship to be based on trust, something that is in line with previous findings (Kakabadse et al., 2010; Kakabadse et al., 2006; Roberts, 2002). In effect, trust appears to function as an important quality which drives supportive behavior by role incumbents. High levels of trust mean that many role constraints perceived by role incumbents in face of strategic tension can be removed through open debate and collaboration, enabling the formation of responses not otherwise available.

"I have experience of it (i.e. CEO-Chairperson relationship) not working and nothing works, it's like almost an all or nothing type thing. Trust absolutely critical, clear communication, very open door policy. It's got to be a good dialogue, but trust is critical." (Chairperson)

"The CEO in my opinion needs to know that the Chairperson is rooting for her, that challenge, question, but the challenge and questioning and rigour, but that really believe and help you be successful, and I never, throughout our career working together, doubted that." (CEO)

Open dialogue and communication has been found to be the basis on which to build a platform of trust. For trust to develop there needs to be intense 'routine interactions' between the two roles (Roberts, 2002), and this requires time. In the interviews, the time that the chairperson can give to the role was emphasised by a number of participants, corroborating 
findings from previous studies (Coombes and Wong, 2004; Kakabadse et al., 2006; Stewart, 1991).

"... and we have no relationship between the CEO and Chairperson because there'd been no time to build a relationship. So it was not a good start. And if I'm honest it just went downhill from there...". (CEO)

"We had become very comfortable in our roles and when we got a new Chairperson it became apparent that we should have spent a lot more time together explaining our thought processes about what we're going to do, why we're going to do those. I just carried on in the assumption that the Chairperson knew what I was doing". (CEO)

CEOs that succeeded in handling strategic tensions reported a much higher frequency and

quality in interacting with the chairperson.

"I'd have a lot of conversations with [chairperson's name] so in a way you're just trying to calibrate, so this is what I think we should do, let's calibrate that. Initially you had no time so you were basically saying we calibrated it crudely we're just going to do it but as time went on you were able to calibrate that more, think more, get more data and think about how you refined it". (CEO)

"When we had one of our biggest issues, I probably spoke to him three times a day. And it's interesting to reflect, why would I talk to somebody three times a day if we loved each other and I, he was, why am I ringing him? I'm ringing him for two reasons: one is to get his advice on an issue because I think he's going to add something, because if I thought I was just going to hear my echo, why would I ring somebody three times a day? I trust and respect him". (CEO)

Prior work pointed to 'affective philos' (Kakabadse et al., 2010) and 'relational social capital', defined as the personal relationships that individuals develop through an history of interactions, and which include trustworthiness and enable social action (e.g. Granovetter, 1992; Nahapiet and Ghoshal, 1998; Putnam, 1993), as critical qualities for chairperson-CEO relationship effectiveness. Trust enables particularly the CEO, but also the chairperson, to raise strategic tensions in the relationship without fear of recrimination or loss of face (Kakabadse et al., 2006). Hence, the presence of high levels of trust in the relationship alleviates the affective dimension of strategic paradoxical tensions, reduces anxiety and defensiveness, and allows tensions to be raised and confronted in the relationship (e.g. Lewis, 2000; Smith and Lewis, 
2011). It provides a context in which the CEO can think provisionally, and which acknowledges the ambiguities and uncertainties inherent in decision-making (Roberts, 2002).

Complementary skills, experiences and perspectives. Having complementary skills, experiences, and perspectives has been found to be of critical importance when addressing developing tensions in the relationship (Roberts, 2002). The presence of 'shared sensemaking' (Kakabadse et al., 2010) or 'cognitive social capital', which 'refers to those resources providing shared representations, interpretations and systems of meaning among parties' (Cicourel, 1973, cited in Nahapiet and Goshal, 1998, p.244) allows both roles to come to a shared understanding of the tensions. Many accounts stressed the critical importance of shared understanding in responding to strategic tensions.

"You've got to have a chairperson and a chief executive who have a, the same view on that subject. If you were in a situation of that nature, I don't think you could have the chairperson having one view and the chief executive having another. Ijust, I can't see it. It's just so big. And if the chief executive and the chairperson have differing views they've really got to hammer it out and come to a single view before it starts to get stress or pressure tested with the board and everyone else". (CEO)

In particular, chairperson industry and international experience was found to be a critical resource to enable shared sensemaking.

"I sometimes question whether he had the right experience. Had never really been thrust into the limelight of political scrutiny and public scrutiny like this. It came as a bit of a shock to him and I wouldn't say he wasn't bright enough but he probably didn't have the experience". (CEO)

Raising and accepting paradox and tension is difficult, because it produces anxiety and often defensive responses (e.g. Lewis, 2000; Sundaramurthy and Lewis, 2003). Moreover, CEOs are often expected to bring before the board clearly-held views (which may stress one side of the strategic tension) - "They are the messengers of the solutions, not the problems" (Fredberg, 2014: 178). 
The relationship qualities outlined above emerged as critical for allowing the negotiation of role boundaries that are adequate for responding to strategic tensions.

\section{Delineating role boundaries}

Role boundary delineation has been raised as a critical dimension of chairperson-CEO relations (Stewart, 1991; Kakabadse et al., 2006). Our findings indicate that boundary management is a dynamic negotiated process that depends both on the role incumbents' interpretation of their own roles, as well as the circumstances surrounding the relationship and which are ever-evolving. Whilst normative prescriptions and conventional wisdom state that the chairperson runs the board and the CEO runs the firm (FRC, 2016), our findings suggest that boundary management is dynamic and dependent on the context, particularly when the firm's strategic direction and competitive advantage is unclear. Delineating role boundaries inevitably generates tensions because the role incumbents may not always share the same understanding of the boundaries or perceive the need for re-arranging boundaries according to circumstantial needs. Remaining fixed on normative role boundaries may facilitate the nonexecutive chairperson to hold the CEO accountable, as well as provide the CEO with the authority to make and implement strategic decisions, but often reveals itself to be non-adaptive to the strategic tensions that emerge in uncertain and complex contexts.

Some CEOs and chairperson expressed views of the conventional role boundaries, with a clear distinction between executive and non-executive domains. This corresponds to the chairperson's role as consultant (Stewart, 1991) where initiative to seek advise is at the CEOs discretion.

"I said to the CEO, look I'm not going to try and do your job, I'm a resource, use me as you see fit. I thought we had quite a constructive relationship and some, in my mind, some really good discussions about the things he was grappling with in the business". (Chairperson) 
"I think the chairperson runs the board and the CEO runs the business. That's the way it should work. That's really a CEO's job, isn't it, not the Chairperson's job. You're there to be used as a resource if you're asked to help with something". (Chairperson)

Other accounts provided a much more flexible and dynamic interpretation of role boundaries. In some situations role boundaries became less important, and skills and experiences that could contribute to handling business tensions became the criteria for effectiveness. These arrangements give rise to what Stewart (1991) termed the chairperson as a 'partner' to the CEO.

"The chairperson and chief executive work as a team. In a good team you don't all do the same thing, there's a centre forward and a centre back, and in a difficult situation the chairperson has to move into a, you could call it an executive role, but it's a more a, more of a leadership role and the chief executive because there's so much to do, is taking a line of responsibility for the operation". (CEO)

"He'd be dealing with things that I should have been dealing with and I was dealing with a lot of things which, in the truth, he should have been dealing with, but because I had personal relationships with, or, it just didn't work that way. You've got this common aim, rather than not my job, chairperson's job, or not my job, chief executive's job". (CEO)

Other CEOs established the boundaries around operations and strategy. The operational day-to-day is seen as exclusively the CEO's responsibility, while regarding strategic decisions the chairperson is perceived to have the legitimacy to intervene and advise.

"That depends a bit from the situation. In the daily operation I don't seek his advice because otherwise he would have taken the role, on strategic moves definitely...And then he is playing exactly the right level of mixing in and keeping out. But he is really somebody... I couldn't imagine a better chairperson for the time being". (CEO)

Some chairpersons revealed different preferences in terms of role boundary management. They expect more involvement in strategy and choose to intervene more in terms of what the CEO can do, suggesting that whether to support or challenge CEO actions will depend on the particular challenge and on the circumstances the firm is facing.

“...The CEO would say I'm sure, I stayed involved too far, too long, all chief executives say that. Unless you can manage, that tension is going to be there and you've got to be prepared to manage it. That's the trouble with it, my view is the chairperson's job is somewhere between half a day a week and seven days a week, it's all the situation and 
let's face it, if the chief executive goes under a bus, you're the next one up, and there are times when you have to be very engaged, and you're not an operating executive". (Chairperson)

Boundary management is often referred to by chairpersons as "a balance between accelerating and pulling the brake", denoting the chairperson's role as both a support and a constraint to the CEO's discretion. This balance often depends on the circumstances that the firm faces. Some CEOs react rather negatively when chairpersons limit their discretion. Two CEOS exited the company in conflict with their chairperson due to disagreements on role boundaries, as exemplified in the following interview extracts:

"At first we collaborated, but as things got more stressful, so that relationship became more and more difficult, I remember, he said, you're the accelerator and I'm the brake, I thought no, I don't need no brake thank you very much, it's hard enough doing stuff as it is without having somebody who's the brake, you know, what do I need a brake for?". (CEO)

"I think what you do as a chairperson is you provide the framework for the painting and then you let the CEO paint. And depending on the capabilities and the development of a CEO you either narrow the frame and you say, this is where you can paint or you're widening and say paint it. So as a chairperson you set the boundaries." (Chairperson)

Boundary management is a critical choice for the chairperson, which depends on the firm's specific challenges and the CEO's own abilities and development. This choice is, however, not without tension, and CEOs may react against the attempts of chairpersons to restrict and control CEO action or even disregard the chairperson's advice.

Role delineation provides the structure within which the chairperson and the CEO can act, and therefore determines which role(s) the chairperson can play in relation to the CEO.

\section{Responses to Strategic Tensions: Shared Leadership and CEO-Led}

Emerging findings suggest there exist two fundamental approaches for chairpersons and CEOs to work effectively when dealing with strategic tensions at the top: i) a shared leadership approach to tensions and; ii) a CEO-led approach to tensions. 
Shared leadership approach to strategic tensions. Shared leadership has been defined as the "dynamic, interactive influence process among individuals in groups for which the objective is to lead one another to the achievement of group or organizational goals or both" (Pearce and Conger, 2003, p. 1). Some evidence of shared leadership between CEOs and chairpersons has been put forward previously by Stewart (1991), and more recently theoretically modeled for boards (Vandewaerde et al., 2011). But apart from these the conventional wisdom that the chairperson leads the board and the CEO leads the firm overwhelmingly dominates research. In our study, we found several cases of shared leadership in handling strategic tensions. Shared leadership entails a specialisation of function (Hodgson et al., 1965), with each role incumbent taking one side of the strategic paradox. Paradox theory describes strategies of separating efforts to focus on both sides of a tension as effective in handling strategic paradox (e.g. Lewis et al., 2014; Smith and Lewis, 2011). This allows business leaders to more effectively address both unique and contradictory elements as well as interdependencies of strategic paradoxes such as exploration and exploitation (e.g. Adriopoulos and Lewis, 2009). Integration of these competing demands occurs in the relationship between the chairperson and the CEO, and has been suggested for top management teams in previous studies (Smith and Tushman, 2005; Tushman et al., 2011). This requires that the tension of control-collaboration needs to move away from the traditional governance prescriptions that state that the chairperson must not have executive responsibility. This would allow chairpersons to remain independent to exert their monitoring and control role (Albanese et al., 1997; Jensen and Meckling, 1976). A shared leadership approach to tensions needs less emphasis on the control role, and more emphasis on the collaboration or stewardship role of the chairperson (Davis et al., 1997). Table II provides examples of cases and quotes illustrating the shared leadership approach. In one global creative company, the chairperson and the CEO shared the leadership position whilst undergoing a difficult restructuring process. The danger was that the dominant frame would be that of 
financial and economic stability, which could jeopardize the creative side of the business. Both the Chairperson and the CEO were able to recognize this danger, providing leadership to each side of the tension whilst ensuring frame integration at the top (Gilbert, 2006). Leadership decided to create an independent division fully dedicated to distribution and sales, instructed to deal with each request from production as a business case. The Chairperson (a creative) led the creative division and the CEO (a financier) led the distribution and sales division. This leadership model provided the mechanism to handle contradictory and quite opposing elements that would otherwise have seemed irreconcilable.

Other examples have emerged where failure to adopt such a mechanism had damaging consequences to the organization and some of its actors. In a large infrastructure company, the CEO was struggling to handle operation and short-term demands, whilst still being able to deal with a multiplicity of stakeholders who influenced the strategic and long-term success of the company. The CEO needed to handle and define strategic, long-term success, to ensure that the right short-term operational decisions were made. The CEO recognised that he needed to share more of the leadership role with the chairperson (see table II, second line for detail). The chairperson would deal with the strategic and long-term aspects of the business, and the CEO with the more operational and short-term issues. However, the CEO emphasised the chairperson's lack of appropriate stakeholder management experience and time to devote to the role as barriers in adopting such a response. This dysfunction led the CEO to polarise around operations and the short term (Lewis, 2000), leaving the long-term challenges unaddressed. This had enormous consequences, not only for the company but also for the wellbeing of the CEO. Table III provides evidence of where this approach was utilised. 
Table III: Chairperson-CEO Leadership Approaches: tensions and reconciliatory responses (Shared Leadership)

\begin{tabular}{|c|c|c|c|c|}
\hline Model I & Strategic Tensions & Quotes - Examples & Responses to Tensions & Quotes - Examples \\
\hline 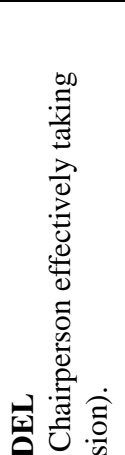 & $\begin{array}{l}\text { Exploitation and } \\
\text { Exploration } \\
\text { Tight (commercial) } \\
\text { and Loose (creativity) }\end{array}$ & $\begin{array}{l}\text { "..[the company] is still the best production } \\
\text { company. Where it needs to learn is to also } \\
\text { become the best exploiting company of its } \\
\text { field".(CEO) } \\
\text { "You need to give some rein and they need } \\
\text { to be able to exploit their own talents and } \\
\text { they need some looseness ...but you need } \\
\text { to give them rules as well. You give } \\
\text { leeway and you encourage creativity and } \\
\text { you hope there is enough freedom for } \\
\text { people to excel... at the same time you } \\
\text { create a system that, to a large extent } \\
\text { should be invisible to them". (CEO) }\end{array}$ & $\begin{array}{l}\text { Split roles and Integrate: Split the } \\
\text { production and distribution businesses and } \\
\text { hold them to different standards. Chairperson } \\
\text { (creative) provided leadership to the } \\
\text { production division and the CEO (financier) to } \\
\text { the distribution division. Integration occurred } \\
\text { at the top within the CEO-Chairperson } \\
\text { relationship. }\end{array}$ & $\begin{array}{l}\text { "The UK and US entities report to [chairperson's name], as being the heart } \\
\text { of creativity, and [executive's name] who runs the worldwide distribution } \\
\text { division reports to me.... if there is a conflict it can only be resolved at } \\
\text { board level....and then it is up to the chairperson and to me to come to a } \\
\text { verdict and make a decision, and that's the sort of tension that you feel in } \\
\text { the business and it's the way we resolve it, and we've got other examples } \\
\text { that come close to it". (CEO) } \\
\text { "In a good team you don't all do the same thing. There's a centre forward } \\
\text { and a centre back, and in a crisis the Chairperson has to move into a, you } \\
\text { could call it an executive role, but it's more of a leadership role and the } \\
\text { chief executive because there's so much to do, is taking a line of } \\
\text { responsibility for the operation". (CEO) }\end{array}$ \\
\hline 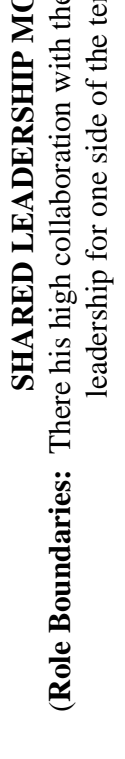 & $\begin{array}{l}\text { Short-term and Long- } \\
\text { term } \\
\text { Operational and } \\
\text { Strategic }\end{array}$ & $\begin{array}{l}\text { "I used to get a lot of operational } \\
\text { questions. All the time I was being brought } \\
\text { to an operational perspective when a Chief } \\
\text { Executive ought to be able to be dealing } \\
\text { with the longer term, the bigger picture } \\
\text { with the stakeholders." (CEO) } \\
\text { “...questioning about what's the role, but } \\
\text { we never got any answers to that and the } \\
\text { company's still in the same situation now, } \\
\text { that it really doesn't know what success } \\
\text { means to the company and it just exists. } \\
\text { And that's a difficult place to be". (CEO) }\end{array}$ & $\begin{array}{l}\text { Polarization: the CEO emphasized } \\
\text { operational and the short-term and left the } \\
\text { strategic and long-terms unaddressed. } \\
\text { However, he needed to clarify and address the } \\
\text { longer term to be able to take the right } \\
\text { decisions at the operational level. } \\
\text { Suppressing: the Chairperson has ignored the } \\
\text { difficulties the CEO was facing in dealing } \\
\text { with both short-term, operational and long- } \\
\text { term, strategic elements. }\end{array}$ & $\begin{array}{l}\text { "I started with a smile and it just, it does get you down in the end. Now I'm } \\
\text { sure there are better ways of dealing with this. I'm sure the Board should } \\
\text { have helped me, spotted what was going on. We should have had a much } \\
\text { better division of responsibilities between stakeholder management and the } \\
\text { executive, the operation side. I should have put in a deputy chief executive } \\
\text { or a chief operating officer, I should have used the board more to share the } \\
\text { load". (CEO) } \\
\text { "I should have made sure they understood that I was struggling under the } \\
\text { weight of expectations of multiple stakeholders and trying to deal with } \\
\text { these compromises in a hostile media and political environment and they } \\
\text { should have done more. I sometimes question whether he [chairperson] had } \\
\text { the right experience. He should have been able to see it, I should have made } \\
\text { it more obvious that over the course of six or seven years the political } \\
\text { environment, the contextual environment in which we operated was } \\
\text { changing and we hadn't noticed it, we didn't respond or change our } \\
\text { approach well enough". (CEO) } \\
\text { "Why was I so central? Maybe I let it happen? With hindsight ... why did I } \\
\text { let those buggers stick me out there? And I think if I've have had a more, a } \\
\text { Chairperson with more time...this is a company which probably deserves } \\
\text { more of an executive Chairperson that's there three days a week to } \\
\text { coordinate and stuff like that". (CEO) }\end{array}$ \\
\hline
\end{tabular}


CEO-led approach to tension. The CEO-led approach gives the CEO the ultimate call on how the tension may be handled, but the Chairperson is critical as he/she acts as the chief adviser, the mentor, and the coach to the CEO in dealing with strategic paradoxical tensions. The control-collaboration tension is still tilted toward the collaboration side but is less pronounced when compared to the shared-leadership approach. This approach emphasises the mentoring (Stewart, 1991) and stewardship role of the chairperson (e.g. Donaldson, 1990).

The chairperson needs to be able to support and coach the CEO in handling some of the tensions, but also needs to proactively search for tensions (Lewis et al., 2014) of which the CEO might not be aware. The CEO retains discretion as to the best course of action.

The CEO-led approach requires that the chairperson ensures balanced decision-making that reflects on the tensions faced by the business, is aware of the CEO's emotional (in)stability, can stress-test any idea in its opposing components and is able to 'dissipate waves' and give time for the CEO to understand and handle fundamental tensions. Table IV provides an illustration of cases where this approach was utilised. 
Table IV: Chairperson-CEO Leadership Approaches: tensions and reconciliatory responses (CEO-Led)

\begin{tabular}{|c|c|c|c|c|}
\hline Model II & Strategic Tensions & Quotes - Examples & Responses to Tensions & Quotes - Examples \\
\hline 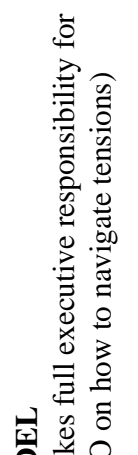 & $\begin{array}{l}\text { Exploitation and } \\
\text { Exploration } \\
\text { Tight (commercial) } \\
\text { and Loose (creativity) }\end{array}$ & $\begin{array}{l}\text { "it's something that you have to try and } \\
\text { manage the best you can, but recognise that } \\
\text { somebody who loves producing television } \\
\text { programmes is probably not going to be } \\
\text { deeply commercial and somebody who } \\
\text { sells advertising, does deals in advertising, } \\
\text { is not going to be deeply creative". } \\
\text { (Chairperson) }\end{array}$ & $\begin{array}{l}\text { Acceptance: The chairperson realizes the } \\
\text { persistent nature of the tension, accepting it as } \\
\text { unavoidable. } \\
\text { Create cognitive recognition: creates } \\
\text { cognitive recognition so people on each side } \\
\text { of the tension understand that the } \\
\text { interdependencies and the need to work } \\
\text { together } \\
\text { Tension integration at the top: The CEO } \\
\text { would then provide a point of integration, at } \\
\text { the top of the organization. }\end{array}$ & $\begin{array}{l}\text { "So you're going to have these slightly difference, dissonant functions and } \\
\text { what you're trying to do is get them to understand each other and } \\
\text { understand why they're different, but understand how, why they have to } \\
\text { work together, so you create at least cognitive recognition, you're not going } \\
\text { not make it, them, they're not going to be a seamless business". } \\
\text { (Chairperson) }\end{array}$ \\
\hline 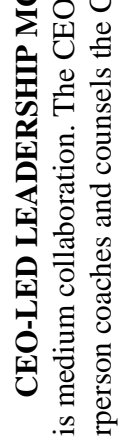 & $\begin{array}{l}\text { Short-term and Long- } \\
\text { term } \\
\text { Old and New } \\
\text { Now and Future }\end{array}$ & $\begin{array}{l}\text { "It had young partners who were just } \\
\text { starting out their career who had little } \\
\text { value in the business at that point in time, } \\
\text { but would be critical to its future. Some } \\
\text { partners had been in the business a long } \\
\text { time, clearly contributed to its past, not } \\
\text { really there for the future, who are going to } \\
\text { be worth a lot of money otherwise. They } \\
\text { failed to articulate in a crisp and clear } \\
\text { fashion a strategy. We had to deal with this } \\
\text { intergenerational issue of the old and the } \\
\text { rich and the new and the poor amongst the } \\
\text { shareholder group". (Chairperson) }\end{array}$ & $\begin{array}{l}\text { Acceptance: the Chairperson coached the } \\
\text { CEO and executive team to accept the tension } \\
\text { was unavoidable } \\
\text { Create cognitive recognition: he supported } \\
\text { the creation of cognitive recognition between } \\
\text { the different shareholder groups and coached } \\
\text { the CEO in finding ways through the tension } \\
\text { Compromise: a compromise type of response } \\
\text { was eventually struck between shareholder } \\
\text { groups. }\end{array}$ & $\begin{array}{l}\text { I had to persuade them that we had to do a different thing, and that was } \\
\text { coaching the management team in each of these areas as to how to do thing } \\
\text { they'd either never done before, not technical issues... an in particular } \\
\text { getting the chief executive to bring his key management along with him, } \\
\text { who would then bring others along with them". (Chairperson) }\end{array}$ \\
\hline 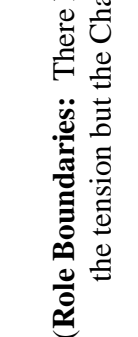 & $\begin{array}{l}\text { Exploration and } \\
\text { Exploitation }\end{array}$ & $\begin{array}{l}\text { "On one hand you had a profitable quite } \\
\text { fast growing retailer and then something } \\
\text { that was fast growing but was sucking } \\
\text { money. And actually one of the problems } \\
\text { in these things is when you combine the } \\
\text { two of them, shareholder's don't know } \\
\text { what to make of it, because you've got } \\
\text { profits being weighted down at a time } \\
\text { when you you've got something very } \\
\text { valuable". (CEO) }\end{array}$ & $\begin{array}{l}\text { Raise and Confront the tension: The } \\
\text { Chairperson confronted the CEO exposing the } \\
\text { contradicting elements and ultimately } \\
\text { supporting the decision to split. Yet, the } \\
\text { leadership remained with the CEO. } \\
\text { Split and Integrate: the two businesses were } \\
\text { split and then integrated. Yet, unlike the in } \\
\text { other situations new management was } \\
\text { recruited into the new business. }\end{array}$ & $\begin{array}{l}\text { "[the chairperson] used to describe it as the law of contrary forces, which } \\
\text { on any proposal he would take an aggressively negative position in order to } \\
\text { test the thing, so it's always difficult to separate how much was positioning } \\
\text { and how much was belief. (CEO) } \\
\text { "Actually, by splitting it apart and actually creating obvious value, you } \\
\text { then changed everything because you could then see the impacts of the two } \\
\text { separate bits."(CEO) }\end{array}$ \\
\hline
\end{tabular}


Table $\mathrm{V}$ below gives an summary of the two configuration models.

Table V: CEO-Chairperson Leadership Model

\begin{tabular}{|c|c|c|}
\hline & SHARED LEADERSHIP & CEO-LED \\
\hline $\begin{array}{l}\text { Chairperson-CEO } \\
\text { Relationship Qualities }\end{array}$ & \multicolumn{2}{|c|}{$\begin{array}{l}\text { - High levels of trust / affective philos / high relational social capital } \\
\text { - Complementarity of Skills and experiences / Shared sense making / high } \\
\text { cognitive social capital } \\
\text { - Chairperson time to devote to role }\end{array}$} \\
\hline Strategic Paradoxes & $\begin{array}{l}\text { - exploration / exploitation } \\
\text { - short-term / long-term }\end{array}$ & $\begin{array}{l}\text { - exploration / exploitation } \\
\text { - short-term / long-term }\end{array}$ \\
\hline Role Boundaries & $\begin{array}{l}\text { Highly Flexible: skills and } \\
\text { experience are more important than } \\
\text { roles. }\end{array}$ & $\begin{array}{l}\text { Moderately Flexible: Roles are more } \\
\text { important than skills and experience. }\end{array}$ \\
\hline Chairperson Role & $\begin{array}{l}\text { Partner: takes executive } \\
\text { responsibility for one side of the } \\
\text { strategic tension, integrating } \\
\text { competing demands in the } \\
\text { Chairperson-CEO relationship }\end{array}$ & $\begin{array}{l}\text { Coach and Counsel: proactively } \\
\text { identifies tensions the CEO might be } \\
\text { grappling with; coaches / counsels / } \\
\text { supports the CEO navigating through } \\
\text { strategic tensions. }\end{array}$ \\
\hline $\begin{array}{l}\text { Reconciliatory } \\
\text { Responses }\end{array}$ & $\begin{array}{l}\text { - Raise and Confront the tension } \\
\text { - Split and Integrate (Chairperson } \\
\text { and CEO) }\end{array}$ & $\begin{array}{l}\text { - Raise and Confront the tension } \\
\text { - Create Cognitive Recognition } \\
\text { - Split and Integrate (CEO) }\end{array}$ \\
\hline
\end{tabular}

Note: compiled by the authors 


\section{Conclusions and contribution}

Twenty five years have passed since Rosemary Stewart published a foundational paper utilising the role theory model of demands-constraints-choices (DCC) (Stewart, 1982) to understand the role dynamics between District General Managers (DGM) and chairpersons in the British National Health System (Stewart, 1991). This study revealed that the role of the General Manager cannot be fully understood without reference to that of the chairperson, since these roles influence each other to a large degree (Stewart, 1991). Stewart asserted that "given the contradictory pressures that could be exerted by these different stakeholders, the nature of the relationship between Chairperson and Chief Executive was particularly important to both in performing their roles..." (Stewart, 1991, p.516). Our study lends support to previous findings on the importance of the chairperson-CEO relationship for handling competing and contradictory demands (e.g. Stewart, 1991; Kakabadse et al., 2006). We find that when firms face strategic paradoxes such as simultaneous demands for exploration and exploitation, the qualities and role delineation of the chairperson-CEO roles relationship may significantly constrain or enable appropriate responses to dealing with strategic paradox. Relationships based on high levels of trust and complementarity of functions where role boundaries are flexible (Hodgson et al., 1965; Stewart, 1991) and where the chairperson can devote time to the relationship (Stewart, 1991; Kakabadse et al., 2006) enable tensions to be raised and confronted in the relationship (Lewis, 2000). They also allow incumbents to separate efforts to focus on different sides of a strategic paradox (Smith and Lewis, 2011; Lewis et al., 2014). When such relationship qualities are absent we have noticed that CEOs become defensive and often polarise around one side of the strategic paradox (Lewis, 2000). We have found evidence of different chairperson roles in relation to the CEO. However, two roles were strongly related with effective handling of strategic tensions. We called these the shared leadership approach to tensions and the CEO-led approach to tensions. These correspond with what Stewart (1991) 
termed respectively partner and mentoring chairperson roles. Results suggest that in the sharedleadership approach, role boundaries become less important, and the complementarity of skills and experiences required in handling the strategic tension become more salient.

The study finds that during periods where strategic tensions become salient due to resource scarcity (Smith and Lewis, 2011), the top roles become more collaborative and interdependent, with the chairperson and CEO often sharing leadership and even more frequently the chairperson acting as a mentor and adviser to the CEO, seeking to positively influence his/her views (Stewart, 1991) on how to address strategic tension.

This raises interesting questions about the governance literature, which has previously argued that during times of poor performance the chairperson should remain independent from the CEO and focus on a control role, shifting to a more collaborative role when firm performance improves (Sundaramurthy and Lewis, 2003).

The importance of the chairperson role in determining the framework within which the CEO can act at his/her own discretion, leadership role-sharing, and mentoring and coaching the CEO all have an impact on how strategic tensions are handled. We urge studies looking at how the $\mathrm{CEO}$ role manages strategic paradoxes to begin to look at governance factors such as the chairperson-CEO relationship, board composition and even ownership structure have an impact on CEO choices over important strategic paradoxes of short-term and long-term investment and exploration and exploitation activities.

This study has important practical implications for chairpersons and CEOs. First it shows that conventional role boundaries may not serve well when the company is facing strategic tensions and needs to recover performance. Chairpersons and CEOs need to be prepared to work together more closely, even to forgo traditional boundaries (even if temporarily) and become joint leaders of the business. Second, chairpersons must be acutely aware of the strategic tensions facing the business and which the CEO may or may not be aware 
of. Chairpersons need to be prepared to intervene and ensure strategic tensions are recognized and acted upon by the CEO. Chairperson intervention may take the form of advise and mentoring, or, in some cases it requires a true shared leadership model whereby both the chairperson and CEO own one side of the tension and work through it in close collaboration. 


\section{References}

Andriopoulos, C., and Lewis, M. W. (2009), "Exploitation-exploration tensions and organizational ambidexterity: Managing paradoxes of innovation", Organization Science, Vol. 20, No. 4, pp.696-717.

Albanese, R., Dacin, T. M., and Harris, I. (1997), “Agents as stewards", Academy of Management Review, Vol. 22, No. 3, pp.609-611.

Argenti, C. (1976), Corporate collapse: Causes and symptoms, McGraw-Hill, New York.

Audia, P. G., Locke, E. A., and Smith, K. G. (2000), “The paradox of success: An archival and a laboratory study of strategic persistence following radical environmental change", Academy of Management journal, Vol. 43, No. 5, pp.837-853.

Boyatzis, R. E. (1998), Transforming Qualitative Information: Thematic Analysis and Code Development, Sage, Thousand Oaks, CA.

Boyd, B. K. (1995), “CEO duality and firm performance: A contingency model”, Strategic Management Journal, Vol.16, No.4, pp.301-312.

Braun, V., and Clarke, V. (2006), "Using thematic analysis in psychology", Qualitative Research in Psychology, Vol. 3, No. 2, pp.77-101.

Brockner, J. (1992), “The escalation of commitment to a failing course of action: Toward theoretical progress", Academy of management Review, Vol.17, No. 1, pp.39-61.

Brosseau, K. R., Driver, M. J., Houriham, G., and Larsson, R. (2006), “The seasoned executive's decision-making style", Harvard Business Review, Vol.84, No. 2, pp.110.

Bryman, A. (1988), Quantity and Quality in Social Research, Unwin Hyman, London.

Byrne, D. (1971), The Attraction Paradigm, Academic Press, New York.

Cadbury Committee Report (1992), Report on the financial aspects of corporate governance, Gee Publishing, London.

Chitayat, G. (1984), "Working relationships between the chairman of the board of directors and the CEO”, Management International Review, Vol. 25, No. 3, pp.65-70.

Cicourel, A. V. (1973), Cognitive Sociology, Penguin Books, Harmondsworth, England.

Coles, J. W., McWilliams, V. B., and Sen, N. (2001), “An examination of the relationship of governance mechanisms to performance", Journal of Management, Vol.27, No.1, pp.23-50.

Coombes, P., and Wong, S. C. Y. (2004), "Chairman and CEO - One job or two?", The McKinsey Quarterly, Vol. 2, pp. 43-47.

Council, F.R. (2011), Guidance on board effectiveness, FRC, London. 
Council, F.R. (2016), The UK Corporate Governance Code, FRC, London.

Creswell, J. (2007), Qualitative Inquiry and Research Design: Choosing Among Five Approaches, $2^{\text {nd }}$ edition, Sage, Thousand Oaks, CA.

Daily, C. M., and Dalton, D. R. (1993), "Board of directors leadership and structure: Control and performance implications", Entrepreneurship: Theory and Practice, Vol.17, No.3, pp.65-82.

Dawis, R. V., and Lofquist, L. H. (1969), Adjustment to work: A psychological view of man's problem's in a work-oriented society, Appleton-Century-Crofts, New York.

Donaldson, L. (1990), "The ethereal hand: Organizational economics and management theory”, Academy of Management Review, Vol. 15, No.3, pp. 369-381.

Donaldson, L., and Davis, J. H. (1991), "Stewardship theory or agency theory: CEO governance and shareholder returns", Australian Journal of Management, Vol.16, No.1, pp.49-65.

Fama, E., and Jensen, M. (1983), "Separation of ownership and control”, Journal of Law and Economics, Vol. 26, No. 2, pp. 301-325.

Farjoun, M. (2010), "Beyond dualism: Stability and change as a duality", Academy of Management Review, Vol. 35, No. 2, pp.202-225.

Fondas, N., and Stewart, R. (1990), Developing role theory for research on managerial jobs and behaviour, Management Research Papers MRP/90/1, Templeton College, Oxford.

Fondas, N., and Stewart, R. (1994), "Enactment in managerial jobs: A role analysis", Journal of Management Studies, Vol.31, No.1, pp.83-103.

Fredberg, T. (2014), "If I say its complex it bloody well will be: CEO strategies for managing paradox", The Journal of Applied Behavioral Science, Vol. 50, No. 2, pp. 171-188.

Gilbert, C. G. (2006), "Change in the presence of residual fit: Can competing frames coexist?”, Organization Science, Vol. 17, No. 1, pp. 150-167.

Gillham, B. (2005), Research Interviewing: The Range of Techniques, Open University Press, New York.

Glaser, B., and Strauss, A. (1967), The Discovery of Grounded Theory, Aldine Publishing, Chicago, IL.

Graen, G. (1969), "Instrumentality theory of work motivation: Some experimental studies and suggested modification”, Journal of Applied Psychology Monograph, Vol. 53, No.2, part II.

Graen, G. (1976), "Role-making processes within complex organizations”, in Dunnette, M. D. (Ed.), Handbook of Industrial and Organisational Psychology, Rand-McNally, Chicago, pp. 1201-1245. 
Grundy, T. (1993), Implementing Strategic Change: A Practical Guide for Business, Kogan Page Limited, London.

Guba, E. G., and Lincoln, Y. S. (2005), "Paradigmatic controversies, contradictions, and emerging confluences", in Denzin, N. K., and Lincoln, Y. S. (Eds.), The Sage handbook of Qualitative Research, $3^{\text {rd }}$ edition, Sage, London, pp. 191-216.

Hahn, T., Pinkse, J., Preuss, L., and Figge, F. (2015), “Tensions in corporate sustainability: Towards an integrative framework", Journal of Business Ethics, Vol. 127, No.2, pp. 297316.

Hahn, T., Preuss, L., Pinkse, J., and Figge, F. (2014), "Cognitive frames in corporate sustainability: Managerial sensemaking with paradoxical and business case frames", Academy of Management Review, Vol. 39, No. 4, pp. 463-487.

Haleblian, J., and Finkelstein, S. (1993), “Top management team size, CEO dominance, and firm performance: The moderating roles of environmental turbulence and discretion", Academy of Management Journal, Vol.36, No.4, pp.844-863.

Hales, C.P. (1986), "What do managers do? A critical review of the evidence", Journal of Management Studies, Vol. 23, No.1, pp. 88-115.

Jarzabkowski, P., Lê, J. K., and Van de Ven, A. H. (2013), "Responding to competing strategic demands: How organizing, belonging, and performing paradoxes coevolve”, Strategic Organization, Vol. 11, No. 3, pp. 245-280.

Jensen, M. C. (1993), "The modern industrial revolution: Exit, and the failure of internal control systems", Journal of Finance, Vol.48, No.3, pp.831-880.

Jensen, M., and Meckling, W. (1976), "Theory of the firm: managerial behavior, agency costs and ownership structure", Journal of Financial Economics, Vol. 3, No. 4, pp. 305-360.

Kahn, R. L., Wolfe, D. M., Quinn, R. P., Snoek, J. D., and Rosenthal, R. A. (1964), Organizational stress: Studies in role conflict and ambiguity, Wiley, New York.

Kakabadse, A. P., Kakabadse, N. K., and Barratt, R. (2006), "Chairman and chief executive officer (CEO): That sacred and secret relationship", Journal of Management Development, Vol. 25, No. 2, pp. 134-150.

Kakabadse, A. P., and Kakabadse, N. K. (2007a), "The return of the chairman", Business Strategy Review, Vol. 18, No. 4, 62-65.

Kakabadse, N. K., and Kakabadse, A. P. (2007b), "Chairman of the board: Demographics effects on role pursuit", Journal of Management Development, Vol.26, No.2, pp.169192. 
Kakabadse, A., and Kakabadse, N. (2008), Leading the Board: The Six Disciplines of WorldClass Chairman, Palgrave, London.

Kakabadse, A. P., Kakabadse, N. K., and Knyght, R. (2010), “The 'chemistry factor' in the chairperson / CEO relationship", European Management Journal, Vol. 28, No. 4, pp. 285-296.

Katz, D., and Kahn, R. L. (1966), The social psychology of organizations, Wiley, New York.

Kroeck, K.G. (2003), "Rosemary Stewart on Management: Behavioral Scribe, Squire of Theory, Pragmatic Scientist", The Leadership Quarterly, Vol. 14, No. 2, pp. 204-216.

Leblanc, R., and Gillies, J. (2005), Inside the Boardroom: How Boards Really Work and the Coming Revolution in Corporate Governance, Willey, Toronto.

Leblanc, R., and Schwartz, M.S. (2007), “The black box of board process: Gaining access to a difficult subject", Corporate Governance: An International Review,Vol. 15, No. 5, pp. 843-851.

Levrau, A., and Van den Berghe, L. (2013), "Perspectives on the decision-making style of the board chair", International Journal of Disclosure and Governance, Vol. 10, No. 2, pp. $105-121$.

Lewis, M. W. (2000), “Exploring paradox: Toward a more comprehensive guide”, Academy of Management Review, Vol. 25, No. 4, pp. 760-776.

Lewis, M. W., Adriopoulos, C., and Smith, W. K. (2014), "Paradoxical leadership to enable strategic agility", California Management Review, Vol. 56, No. 3, pp. 58-77.

Lowe, K. B. (2003), "Demands, constraints, choices and discretion: An introduction to the work of Rosemary Stewart", The Leadership Quarterly, Vol.14, No.2, pp.193-238.

Morck, R., Shleifer, A., and Vishny, R. W. (1988), Alternative mechanisms for corporate control, Working Paper No. 2532, National Bureau of Economic Research.

Nahapiet, J., and Ghoshal, S. (1998), "Social capital, intellectual capital and the organizational advantage", Academy of Management Review, Vol. 23, No. 2, pp. 242-266.

Parry, K.W. (2003), “Of complexity and distillation: Stewart's contribution to understanding what managers really do", The Leadership Quarterly, Vol. 14, No. 2, pp. 216-221.

Patton, M. Q. (2002), Qualitative Research and Evaluation Methods, $3^{\text {rd }}$ edition, Sage, Thousand Oaks, CA.

Pearce, C. L., and Conger, J. A. (2003), Share leadership: Reframing the Hows and Whys of Leadership, Sage, Thousand Oaks, CA. 
Putnam, L. L. (1986), “Contradictions and paradoxes in organizations”, in Thayer, L. (Ed.), Organization Communications: Emerging Perspectives, Ablex Publishing, Norwood, NJ, pp. 151-167.

Putnam, R. D. (1993), “The prosperous community”, The American Prospect, Vol. 4, No. 13, pp. 35-42.

Pye, A. (2005), "The importance of context and time for understanding board behavior", International Studies of Management \& Organization, Vol. 34, No. 2, pp. 63-89.

Roberts, J. (2002), "Building the complementary board. The work of the Plc chairperson”, Long Range Planning, Vol. 35, No. 5, pp. 493-520.

Roberts, J., and Stiles, P. (1999), "The relationship between chairperson and chief executives: Competitive or complementary roles?”, Long Range Planning, Vol. 32, No. 1, pp. 36-48.

Robson, C. (2002), Real World Research, $2^{\text {nd }}$ edition, Blackwell, Oxford.

Saunders, M., Lewis, P., and Thornhill, A. (2009), Research Methods for Business Students, $5^{\text {th }}$ edition, FT Prentice Hall, London.

Schmitt, A. and Raisch, S. (2013), "Corporate Turnarounds: The duality of retrenchment and recovery", Journal of Management Studies, Vol. 50, No. 7, pp. 1216-1244.

Silverman, D. (2013), Interpreting Qualitative Data, $4^{\text {th }}$ edition, Sage, London.

Slatter, S. S. P., and Lovett, D. (1999), Corporate recovery: Managing companies in distress, Beard Books, Washington, DC.

Smith, W. K. (2014), "Dynamic decision making: A model of senior leaders managing strategic paradoxes", Academy of Management Journal, Vol. 57, No. 6, pp. 1592-1623.

Smith, W.K., Binns, A., and Tushman, M.L. (2010), "Complex business models: Managing strategic paradoxes simultaneously”, Long Range Planning, Vol. 43, No. 2, pp. 448-461.

Smith, W. K., and Lewis, M. W. (2011), "Toward a theory of paradox: A dynamic equilibrium model of organizing”, Academy of Management Review, Vol. 36, No. 2, pp. 381-403.

Smith, W. K., and Tushman, M.L. (2005), "Managing strategic contradictions: A top management model for managing innovation streams", Organization science, Vol. 16, No. 5, pp. 522-536.

Stewart, R. (1967), Managers and their jobs. A study of the similarities and differences in the ways managers spend their time (2nd ed.), Macmillan, London.

Stewart, R. (1976), Contrasts in management, McGraw-Hill, Maidenhead, UK.

Stewart, R. (1982), “A model for understanding managerial jobs and behavior”, Academy of Management Review, Vol. 7, No. 1, pp. 7-13. 
Stewart, R. (1991), "Chairperson and chief executive: An exploration of their relationship", Journal of Management Studies, Vol. 28, No. 5, pp. 511-527.

Stewart, R. (2003), "Woman in a man's world", The Leadership Quarterly, Vol.14, No. 2, pp.197-204.

Stiles, P. (2001), “The impact of the board on strategy: An empirical examination”, Journal of Management Studies, Vol. 38, No. 5, pp. 627-650.

Sundaramurthy, C., and Lewis, M. (2003), "Control and collaboration: Paradoxes of governance", Academy of Management Review, Vol. 28, No. 3, pp. 397-415.

Tse, T. (2013), "Paradox resolution: A means to achieve strategic innovation", European Management Journal, Vol. 31, No.6, pp. 682-696.

Tushman, M. L., Smith, W. K., and Binns, A. (2011), "Embracing Paradox”, Working Paper 11-110, Harvard Business School, Boston, MA.

Vandewaerde, M., Voordeckers, W., Lambrechts, F. and Bammens, Y. (2011). "Board team leadership revisited: A conceptual model of shared leadership in the boardroom", Journal of Business Ethics, Vol.104, No.3, pp.403-420. 